\title{
Joggyakorlat
}

\author{
CSIRSZKI MARTIN MILÁN*
}

\section{A felszín alatti vizek védelme a Kúria ítéletének tükrében ${ }^{1}$}

\author{
Groundwater Protection through a Judgment \\ of the Supreme Court of Hungary
}

\begin{abstract}
ABSZTRAKT
A tanulmányban a szerző a Kúria egyik itéletének elemzésére vállalkozik, amelyben elöremutató birói jogértelmezés érhetö tetten a felszín alatti vizek védelmével kapcsolatos tényfeltárási kötelezettség vonatkozásában. A részletek megvilágitása érdekében a szerző felvázolja a felszín alatti vizekkel kapcsolatos szabályozás föbb elemeit. Nemcsak a nemzeti szintü szabályokat ismerteti, hanem az Európai Unió jogalkotási aktusait is. Az eset részletes bemutatása alapján néhány konklúzió megfogalmazására kerül sor.
\end{abstract}

Kulcsszavak: környezetvédelem, felszín alatti vizek, tényfeltárás, joggyakorlat, Kúria

\begin{abstract}
In the study the author analyses a judgment of the Supreme Court of Hungary, in which a progressive judicial interpretation is included concerning the obligation of fact-finding in connection with the protection of groundwaters. Before this, the author presents the legal doctrine regarding groundwater regulation. The regulation is not only drawn up on the national level, but also on the level of European Union. After the detailed presentation of the case, the author makes some suggestions.
\end{abstract}

Keywords: environmental protection, groundwater, fact-finding, case law, Curia

Környezetünk védelme és megóvása a 21. század egyik, ha nem a legégetöbb kérdésköre. ${ }^{2}$ A szakemberek az élet valamennyi területén igyekeznek megoldásokat

* Dr. Csirszki Martin Milán, PhD-hallgató, Deák Ferenc Állam- és Jogtudományi Doktori Iskola, Miskolci Egyetem Állam- és Jogtudományi Kar, Agrár- és Munkajogi Tanszék; e-mail: jogcsm@uni-miskolc.hu. ORCID: 0000-0002-4339-7058.

1 A tanulmány a Miskolci Törvényszék által szervezett Pálinkás György emlékév keretében megrendezett cikkíró pályázatra készült 2019-ben.

${ }^{2}$ Ezt megerősítették az ENSZ Éghajlatváltozási Keretegyezményében részes felek a 2018. december 2. és 16. között Katowicében megtartott 24. konferenciájukon (COP24) valamennyi elfogadott nyilatkozatukban. 
találni, amelyekkel csökkenthető a környezet terhelése, s valamennyi tudományág a maga eszközrendszerét e nemes cél szolgálatába próbálja állítani. Nincs ezzel másképpen a jogtudomány, illetve a jogtudomány reflexiójának középpontjába állított joggyakorlat sem. A jogalkotás szigorodó szabályozási megoldásokkal tud reagálni a fokozatosan romló környezeti viszonyokra, a jogalkalmazás kezében pedig a környezetvédelmi szempontokat a lehető legmesszebbmenőkig szem előtt tartó és hangsúlyozó jogértelmezés áll. A környezetért való felelősség érvényesítésének hatékonyabbá tétele érdekében folyamatosan születnek javaslatok az elméleti és a gyakorlati szakemberektől egyaránt, s a jövő nemzedékek érdekeinek védelmét ellátó biztoshelyettes is megfogalmazta abbéli javaslatát, hogy a szankciórendszert úgy kell átalakítani, hogy az „a kármentesítési feladatok ellátására ösztönözzön, s a bírság ne váljon a gazdasági tevékenység elöre tervezett költségévé”. ${ }^{3}$

Jelen tanulmányban a Kúria egy elvi döntést tartalmazó ítéletén - a Kfv. IV.37.043/2018/7. számú ítéleten (a továbbiakban: ítélet) - keresztül kívánok bemutatni egy esetet, amelyben a felszín alatti vizek védelmével kapcsolatban a kármentesítési felelősség és a bizonyítási teher kérdése játszotta a központi szerepet. Az ügy részleteiből, illetve az ítéletből láthatóvá válik, hogy a bizonyítási terhet megfordító, a környezetkárosodásért és környezetveszélyeztetésért való felelősség vélelme milyen fontos szerepet játszik a környezetvédelmi ítélkezés hatékonyságának fenntartásában. A cikkben elsőként a felszín alatti vizek szabályozásának releváns pontjainak bemutatására törekszem, amelynek keretében nemcsak a kármentesítésre kötelezés, hanem a pénzbírság egyes szabályait is bemutatom. Bár az ügyben a kármentesítés a központi jelentőségű, a környezetvédelem, s ezen belül - természetesen - a vízvédelem is megköveteli a büntető jellegű pénzbírság kiszabásának lehetőségét, ezért az ügy jogi szabályozási hátterénél érdemes pár szót erről is ejteni a teljesebb kép érdekében. Ezt követően az ítélet alapjául szolgáló tényállás közigazgatási hatósági, valamint bírósági szakaszainak feldolgozására kerül sor. Ezek után pedig az ügyhöz kapcsolódó összegző gondolatok megfogalmazására, valamint konklúziók levonására vállalkozom. Véleményem szerint, jelen ítélet kiválóan szemlélteti azt, hogy a jog(gyakorlat) a maga eszközrendszerével képes hozzájárulni a környezetvédelemhez. Bár a jelen tanulmány középpontjában álló ügy megítélésében kizárólag a magyar jogrendszer játszott szerepet, úgy gondolom, hogy az uniós szabályozás megemlítése is indokolt, tekintettel arra, hogy a magyar szabályozás - az uniós tagságunk fennállása óta - erősen beágyazódik az uniós jogba, és annak követelményei determinálják a magyar szabályozást. Ennek megerősítéseként említhető meg, hogy ugyan az uniós joggal való összhang az e tanulmányban tárgyalt ítélet kapcsán nem merült fel, de az Európai Unió Bíróságának (a továbbiakban: EUB) a gyakorlatában találunk olyan példát, amelyben jelen jogesetben is meghatározó jogszabályi rendelkezés képezte a vita tárgyát. Abban az EUB annak a kérdésében foglalt állást, hogy a szennyező fizet elvét túllépő magyar szabályozás, azaz az ingatlantulajdonos és az ingatlanhasználó egyetemleges

${ }^{3}$ Biztoshelyettesi jogalkotási kezdeményezés a környezeti felelősség hatékonyabb érvényesítése érdekében. Jövő nemzedékek érdekeinek védelmét ellátó biztoshelyettes, Budapest, 2017. december 7. http://www.ajbh. hu/documents/10180/2776705/JNBH_jogszabalyi_javaslat.pdf/61968154-4a75-bf07-0479-10a667263033 (2020. 07. 21.). 
felelőssége az Unió jogával összhangban áll-e. ${ }^{4} \mathrm{~A}$ magyar szabályozás tárgyalása mellett tehát ezért kerülnek felvázolásra az uniós jogi vetületek is.

\section{Az ügy jogi szabályozási háttere}

A bevezetésben ugyan a környezetvédelemröl mint általános tevékenységröl és törekvésröl ejtettem néhány szót, azonban a védelem a gyakorlatban speciálisan, egy-egy környezeti elemre vonatkoztatva tud realizálódni. A környezet védelmének általános szabályairól szóló 1995. évi LIII. törvény (a továbbiakban: Kvt. vagy környezetvédelmi törvény) 4 . § 1 . pontjában meghatározza a környezeti elem fogalmát, amely a következőképpen hangzik: „a föld, a levegö, a víz, ${ }^{5}$ az élövilág, valamint az ember által létrehozott épített (mesterséges) környezet, továbbá ezek összetevői”. A dogmatikában nagyjából, kisebb-nagyobb eltérésekkel ezen elemek mentén épül fel a környezetjog különös része, azaz az egy-egy környezeti elemre vetített szabályok koherens rendszere és az arra felépülő jogtudományi vizsgálódások. Az általam kiválasztott ítélet történeti tényállásának középpontjában a felszín alatti vizek védelme jelenik meg, így indokoltnak tartom, hogy egy rövid betekintést adjak a kérdéskör szabályozásába és felépítésébe. ${ }^{6}$

Elöljáróban még érdemes megemlíteni, hogy az általánosságban is elmondható, hogy a felszín alatti vizek szennyezése sokkalta kevésbé egyértelmü, mint a felszíni vizeké. Talán ez indokolja azt, hogy az utóbbira nagyobb figyelmet fordítanak. Számos esetben egy meghatározott felszín alatti víztest problémájának forrását nem is lehet feltárni, ha a szennyezést nem pontszerű szennyező forrás okozza, ${ }^{7} \mathrm{~s}$ ez tovább fokozza a nehézségeket. A választott jogesetben azonban ez a nehezítő tényező nem volt jelen, hiszen a pontszerü forrásból származó szennyezés viszonylag könnyen beazonosítható volt, amint erre a tényállás ismertetése során a későbbi fejezetekben ki fogok térni.

Mivel Magyarország 2004-töl az Európai Unió tagja, a felszín alatti vizek szabályozása kapcsán is megkülönböztethetünk első körben két szabályozási szintet, amely egymással szoros összefüggésben áll. Az Unió és a tagállamok közötti megosztott hatáskörök egyike a környezetvédelem, ${ }^{8}$ ezen belül pedig értelemszerüen a felszín alatti vizek védelme is, így az Uniónak lehetösége nyílik arra, hogy a tagál-

\footnotetext{
${ }^{4}$ C-129/16. sz., Túrkevei Tejtermelö Kft. kontra Országos Környezetvédelmi és Természetvédelmi Főfelügyelőség ügyben 2017. július 13-án hozott ítélet (ECLI:EU:C:2017:547).

${ }^{5}$ Lásd a két jelentős monográfiát, amely a vízjoggal foglalkozik, $\mathrm{s}$ amelyekben a felszín alatti vizekkel kapcsolatos jogi szabályozás is részletesen elemzésre kerül: SzILÁGYI János Ede: Vízszemléletü kormányzás vízpolitika - vízjog: kitekintéssel a vízgazdálkodásra és a víztudományra. Miskolci Egyetemi Kiadó, Miskolc, 2018.; SzILÁGYI János Ede: Vízjog - Aktuális kihívások a vizek jogi szabályozásában. Miskolci Egyetemi Kiadó, Miskolc, 2013.

${ }^{6}$ Lásd részletesen SzILÁGYI János Ede: A vízjog és a víz jogi szabályozásának rendszere és egyes aktuális kérdései az Európai Unió keretében. Agrár- és Környezetjog, 2019/26, 255-298. (DOI: 10.21029/JAEL. 2019.26.255).

${ }^{7}$ BARKER, Albert P.-BURLEIGH, Richard B.: Agricultural chemicals and groundwater protection: Navigating the complex web of regulatory controls. Idaho Law Review, 1993-1994/3, 445.

${ }^{8}$ Európai Unió Múködéséről szóló Szerződés, 4. cikk (2) bekezdés e) pont.
} 
lami szabályozást jogalkotási aktusaival befolyásolja. Ez a felszín alatti vizek esetében az irányelveken keresztül történő szabályozást jelenti, amely két fontos jogalkotási aktusban ölt testet: az egyik a vízpolitika terén a közösségi fellépés kereteinek meghatározásáról szóló irányelv, ${ }^{9}$ míg a másik a felszín alatti vizek szennyezés és állapotromlás elleni védelméről szóló irányelv. ${ }^{10}$ Előbbi meghatározza a felszín alatti víz fogalmát is: „mindaz a víz, amely a föld felszíne alatt a telített zónában található, és közvetlen kapcsolatban van a talajjal vagy az altalajjal". ${ }^{11}$ Ezek mellett, az uniós környezetvédelem általános jogalkotási aktusaként meg kell említeni a környezetért való felelősségről szóló irányelvet is. ${ }^{12} \mathrm{Az}$ első szabályozási szint tehát az Unió szintje, amely alatt helyezkedik el a második szinten a magyar szabályozás, amelynek immáron a fölötte álló szinttel is koherens egységet kell alkotnia, hiszen az irányelvek nemzeti jogba történő átültetése tagállami kötelezettség.

A második szintet alkotó magyar szabályozás környezetvédelmi kódexének tekinthető az általános szabályokat összefog(lal)ó Kvt., amelynek 18-21. §-ai foglalkoznak a víz védelmével. A víz védelme nemcsak a felszíni, hanem a felszín alatti vizekre is kiterjed,,$^{13}$ amelynek keretében a környezet igénybevételét és használatát úgy kell megszervezni és végezni, hogy a vizek állapotára vonatkozó környezeti célkitüzések teljesüljenek, így különösen az, hogy a felszíni és a felszín alatti vizek állapota ne romoljon, valamint a felszíni és felszín alatti vizek jó állapota a külön jogszabály szerinti környezeti követelmények teljesítése révén megvalósuljon. ${ }^{14} \mathrm{~A}$ Kvt.-t néhány rendelkezéssel a vízgazdálkodásról szóló 1995. évi LVII. törvény (a továbbiakban: Vgtv.) is kiegészíti, amelynek legjelentősebb védelmi rendelkezése az, hogy a felszín alatti vizet csak olyan mértékben szabad igénybe venni, hogy a vízkivétel ${ }^{15}$ és a vízutánpótlás egyensúlya minőségi károsodás nélkül megmaradjon. ${ }^{16}$ Ugyanakkor a magyar környezetjogi szabályozásban a kérdéskör környezeti elemre vetített speciális jogforrását a felszín alatti vizek védelméröl szóló 219/2004. (VII. 21.) Korm. rendelet (a továbbiakban: kormányrendelet) adja, amely akárcsak a vízpolitikai irányelv, egy speciális fogalommeghatározással operál: a felszín alatti víz „a terepfelszín alatt a földtani közeg telített zónájában (így különösen a földtani képződmények pórusaiban, hasadékaiban) elhelyezkedő víz". ${ }^{17}$

A kormányrendelet célkitüzései egyértelmüek: meg kell állapítani a felszín alatti vizek jó állapotának biztosításával és annak fenntartásával, szennyezésének foko-

${ }^{9}$ Az Európai Parlament és a Tanács 2000/60/EK irányelve (2000. október 23.) a vízpolitika terén a közösségi fellépés kereteinek meghatározásáról. OJ L 327, 22/12/2000, 1-73. Special edition in Hungarian: Chapter 15, Volume 005, 275-346. (a továbbiakban: vízpolitikai irányelv).

${ }^{10}$ Az Európai Parlament és a Tanács 1855/2006/EK irányelve (2006. december 12.) a felszín alatti vizek szenynyezés és állapotromlás elleni védelméröl. HL L 372, 27/12/2006, 19-31.

11 Vízpolitikai irányelv 2. cikk, 2. pont.

${ }^{12}$ Az Európai Parlament és a Tanács 2004/35/EK irányelve (2004. április 21.) a környezeti károk megelőzése és felszámolása tekintetében a környezeti felelősségröl. OJ L 143, 30.4.2004, 56-75.

${ }^{13}$ Kvt. 18. § (1).

${ }^{14}$ Kvt. 18. § (5) a-b).

${ }^{15}$ A felszín alatti vízkivételekkel kapcsolatban lásd: SzILÁGYı János Ede-BARANYAI Gábor-SzŰcs Péter: A felszín alatti vízkivételek liberalizálása az Alaptörvény és az európai uniós jog tükrében. Hidrológiai Közlöny, 2017/4, 14-23.

16 Vgtv. 15. § (1).

17 Kormányrendelet, 3. § 9. 
zatos csökkentésével és megelőzésével, hasznosítható készleteinek hosszú távú védelmére alapozott fenntartható vízhasználatával, illetve a földtani közeg kármentesítésével összefüggő feladatokat, jogokat és kötelezettségeket. ${ }^{18}$ Rendkívül fontos, hogy a kormányrendelet a felszín alatti vizek jó állapotának elérését objektív követelményként jeleníti meg, $\mathrm{s}$ a szennyezés csökkentését nem kizárólag a mindenkori kibocsátásokhoz viszonyítva írja elő. ${ }^{19} \mathrm{~A}$ felszín alatti vizek védelme pedig kétirányú: van egy mennyiségi és van egy minőségi aspektusa. Van olyan nézet, amely a mennyiségi aspektust a vízgazdálkodással azonosítja, de megfelelöbb kategóriának tủnik azt a vízkészlet-gazdálkodással párhuzamba állítani. ${ }^{20} \mathrm{~A}$ minőségi vízvédelem alá vonható be például „a szennyező anyagok felszín alatti vízbe vezetésének vagy mélyművelési bányákban történő elhelyezésének a tilalma, máshol korlátozása, illetve engedélyhez kötése, s nem utolsósorban a felszín alatti vízre és a földtani közegre megállapított szennyezettségi határértékek". ${ }^{21}$ Ezt a kettősséget, azaz a mennyiségi és a minőségi oldal egymás mellett történő szerepeltetését a vízpolitikai irányelv is kiemeli akként, hogy a környezetvédelem céljából a mennyiségi és a minőségi szempontokat fokozottan kell integrálni a felszíni és a felszín alatti vizek esetében egyaránt, mégpedig kiemelt figyelmet fordítva a víz természetes körforgására. ${ }^{22} \mathrm{~A}$ felszín alatti vizek mennyiségi és minőségi védelmének integrált kezelése elkerülhetetlen, hiszen ezen szempontok között szoros kapcsolat van: a felszín alatti víz szennyezése csökkenti a hasznosítható felszín alatti víz mennyiségét, a felszín alatti vízből történő vízkivétel pedig minőségi problémákat okozhat olyan formában, hogy növekedik a szennyezőanyagok áramlása ${ }^{23}$ és ezáltal más vizekbe történő bejutása. ${ }^{24}$

A felszín alatti vizek védelme kapcsán három kategóriát állítottak fel, amelyek tekintetében a fentebb említett mennyiségi és minőségi védelmi szempontokat érvényesíteni kell: vannak fokozottan érzékeny, érzékeny, valamint kevésbé érzékeny területek. Mind a mennyiségi, mind a minőségi védelem meghatározó eszközeit a határértékek jelentik, amelyekre tekintettel a „környezetvédelmi hatóság egyedi esetekre folytat le engedélyezési eljárást, vagy határoz meg kötelezettségeket". ${ }^{25}$

A jogkövetkezmények kérdéskörében is érdemes néhány specialitást megemlíteni. A felszín alatti vizek védelmével kapcsolatos bírság részletes szabályait a

\footnotetext{
${ }^{18}$ Kormányrendelet, 1. §.

19 FODOR László: Környezetjog. Debreceni Egyetemi Kiadó, Debrecen, 2014, 224.

${ }^{20}$ SZILÁGYI János Ede: A vízjogi szabályozási csomópontok továbbfejlesztési lehetőségei. Pro Futuro, 2015/2, 45.

${ }^{21}$ FODOR: i. m., 225.

22 Vízpolitikai irányelv, Preambulum (34).

${ }^{23} \mathrm{Az}$ angol geológiai szakirodalomban ezt nevezik contamination plume-nak, amikor a pontszerủ szenynyező forrásból származó anyag bejut a felszín alá, majd számos tényezőtől függően, így például a felszín alatti víz folyási irányától, a víztartó-képződmény jellegétől, illetve a szennyező anyag sürüségétől függően továbbhalad, és áramlik a felszín alatt, további területeket „megfertőzve”. http://www.dwa.gov.za/Groundwater/Groundwater_Dictionary/index.html?introduction_contamination_plume.htm (2019. 11. 04.).

24 Jakeman, Anthony J.-Barreteau, Olivier-Hunt, Randall J.-Rinaudo, Jean-Daniel-Ross, Andrew (eds): Integrated Groundwater Management - Concepts, Approaches and Challenges. Springer International Publishing, 2016, 189. (DOI: 10.1007/978-3-319-23576-9).

${ }^{25}$ Lapsánszky András (szerk.): Közigazgatási jog - Fejezetek szakigazgatásaink köréböl, II. kötet - Gazdasági közigazgatás, infrastruktúra igazgatás. CompLex, Budapest, 2013, 195.
} 
kormányrendelet 36-40. §-ai szabályozzák, ugyanakkor - véleményem szerint a bírságolástól jóval hatékonyabb és előremutatóbb intézkedés a kármentesítésre kötelezés. A kármentesítés olyan helyreállítási intézkedés, amely a felszín alatti víz és földtani közeg károsodásának enyhítésére, az eredeti állapot vagy ahhoz közeli állapot helyreállítására, valamint a felszín alatti víz által nyújtott szolgáltatás helyreállítására vagy azzal egyenértékű szolgáltatás biztosítására irányul, így különösen az a múszaki, gazdasági és igazgatási tevékenység, amely a veszélyeztetett, szenynyezett, károsodott felszín alatti víz, illetőleg földtani közeg megismerése, illetőleg a szennyezettség, károsodás és a kockázat mértékének csökkentése, megszüntetése, továbbá monitorozása érdekében szükséges. ${ }^{26}$ Röviden az mondható el, hogy a kármentesítés nem más, mint „a már bekövetkezett szennyezések, károsodások felszámolása”. ${ }^{27}$ A kormányrendelet pedig egyértelmü kötelezettségként rögzíti, hogy a pontszerü szennyező forráshoz tartozó, valószínűsíthető szennyezettség, illetve károsodás esetén a köz érdekében kármentesítést kell végezni. ${ }^{28}$ Ezt azért tartom sokkal előremutatóbb intézkedésnek, mint a bírságot, mivel a környezetvédelem jogi szabályozása esetén az elsődleges cél az in integrum restitutio lehető legteljesebb érvényre juttatása, azaz a környezeti állapot olyan mérvű helyreállítása, mintha a szennyezés, a károsodás meg sem történt volna. A bírságolás közvetlen hatással nem jár a környezeti állapot javítását tekintve, csupán közvetetten szoríthatja a károsítót a jogszerű magatartás tanúsítására. Ezzel szemben a kármentesítés, amennyiben azt a kötelezett végrehajtja, közvetlenül szolgálja a környezetvédelem érdekét.

A kármentesítés három szakaszból áll, amelyek szükség szerint megismételhetőek. ${ }^{29} \mathrm{E}$ három szakasz a tényfeltárás, a beavatkozás, valamint a monitoring. A tényfeltárás állhat felderítő és részletes vizsgálatból, a monitoring pedig történhet egyrészt a tényfeltárás és a beavatkozás után, másrészt azokkal párhuzamosan. ${ }^{30}$ A tényfeltárás záródokumentáció készítésével fejeződik be, amelynek elfogadásáról a környezetvédelmi hatóság dönt. A beavatkozás beavatkozási terv alapján történik, $s$ befejezését követően szintén egy záródokumentációt kell benyújtani. A monitoring pedig nem más, mint hogy a kötelezett folyamatosan ellenőrzi az első két szakaszban elvégzett tevékenységének „környezetre gyakorolt hatását, eredményességét, továbbá a környezetkárosodás csökkenését, illetve megszünését, illetőleg az egyes szakaszokat követő időszakokban a környezeti állapot változását". ${ }^{31}$

A kötelezett személyét illetően a kormányrendelet úgy rendelkezik, hogy a kármentesítést annak kell elvégeznie, aki a környezetvédelmi törvény 101-102/A. §-ában meghatározottak szerint felelősséggel tartozik. ${ }^{32}$ A hivatkozott szakasz a jogi felelősség általános alapját határozza meg, amikor kimondja, hogy a környezethasználó „...büntetőjogi, polgári jogi és közigazgatási jogi felelősséggel tartozik tevékenysé-

\footnotetext{
${ }^{26}$ Kormányrendelet, 3. § 18.

${ }^{27}$ FodoR: i. m., 225.

${ }^{28}$ Kormányrendelet 21. § (1).

${ }^{29}$ Kormányrendelet, 21. § (5).

30 Kormányrendelet, 21. § (4).

31 BÁNDI: i. m., 451.

32 Kormányrendelet, 21. § (2).
} 
gének a környezetre gyakorolt hatásaiért". ${ }^{33}$ Ezt követően bontja ki a környezetvédelmi törvény az e felelősséghez kapcsolódó egyes, inkább közigazgatási jogi jellegủ részkötelezettségeket. ${ }^{34} \mathrm{E}$ részkötelezettségek között helyet kap például tájékoztatási, kármegelőzési, kárelhárítási, illetve helyreállítási kötelezettség is, amelyek mind azt a végső célt szolgálják, hogy a környezet károsodása esetén az in integrum restitutio biztosított legyen. A környezetre gyakorolt hatásokért való felelősség közigazgatási jellege - egyébiránt - nem csak a magyar környezetvédelmi törvény sajátja. Az Európai Unió környezeti felelősségre vonatkozó, korábbiakban már említett irányelve is - nevével ellentétben - „nem a kártéritési felelősséggel foglalkozik, hanem sokkal inkább közigazgatási típusú felelősségnek mondható". ${ }^{35}$

A Kvt. egy megdönthető vélelmet is felállít a környezetjogi felelősség kötelezettjét illetően, amikor akként rendelkezik, hogy a környezetkárosodásért, illetve a környezetveszélyeztetésért való felelősség - az ellenkező bizonyításáig - annak az ingatlannak a környezetkárosodás, illetve környezetveszélyeztetés bekövetkezésének időpontját követő mindenkori tulajdonosát és birtokosát (használóját) egyetemlegesen terheli, amelyen a környezetkárosítást, illetve környezetveszélyeztető magatartást folytatták. ${ }^{36} \mathrm{E}$ rendelkezésből nemcsak a vélelem rajzolódik ki, hanem az is, hogy az ingatlantulajdonos és az ingatlanbirtokos egyetemleges kötelezettként állnak egymás mellett, és ez fennáll mindaddig, amíg a tulajdonos meg nem nevezi az ingatlan tényleges használóját, és kétséget kizáróan bizonyítja, hogy a felelősség nem őt terheli. ${ }^{37} \mathrm{Az}$ egyetemlegesség egyértelműen annak megerősített biztosítékául szolgál, hogy egy-egy környezetkárosodás ne maradjon felelős nélkül, amely az in integrum restitutio elmaradásához vezethetne. Ugyanakkor fontos leszögezni, hogy ez a rendelkezés „nem közvetlen felelösségi szabály, hanem helytállási jellegü, amely alapján a kötelezett akkor is köteles a környezetszennyező tevékenységéért helytállni, ha ő maga környezetszennyező tevékenységet nem folytat". ${ }^{38}$

A kármentesítésre vonatkozó rendelkezések és a kötelezett személyének meghatározása közötti kapcsolat terén összefoglalóan az mondható el, hogy kármentesítésre az köteles, aki „a szennyezettséget okozó tevékenységet folytatta vagy folytatja, illetve annak jogutódja, a környezeti kárért fennálló felelősséget a szennyezett terület tulajdonjogának megszerzésével vagy egyéb módon átvállalja, valamint a Kvt. 101-102. §-a szerint felelösségre vonható". ${ }^{39}$

Érdemes még pár szót ejteni a közigazgatási jogi felelősség alóli mentesülés esetköreiröl, amit a környezetvédelmi törvény 102/A. § (1) bekezdése szabályoz. Ezek felsorolása rögtön rávilágít arra, hogy objektív felelősségről beszélünk. ${ }^{40} \mathrm{Az}$ első

${ }^{33}$ Kvt. 101. § (1).

${ }^{34}$ Lásd: Kvt. 101. § (2).

${ }^{35}$ BÁNDI Gyula: A környezeti szabályozás útja az európai integrációban, példákkal illusztrálva. lustum Aequum Salutare, 2018/2, 144.

${ }^{36}$ Kvt. 102. $\S(1)$.

${ }^{37}$ Kvt. 102. $\S(2)$.

${ }^{38}$ CsÁk Csilla: A környezetjogi felelösség magánjogi dogmatikája. Miskolci Egyetemi Kiadó, Miskolc, 2012, 56.

39 BÁNDI: i. m., 454.

${ }^{40}$ CsAPó Orsolya: A környezeti felelösség határai - A közösségi jog hatása a magyar szabályozásra az irányelvek tükrében. PhD-értekezés, Budapest, 2015, 201. 
mentesülési esetkörbe tartozik az, ha fegyveres összeütközés, háború, polgárháború, fegyveres felkelés, illetve természeti katasztrófa következménye a környezetkárosodás vagy a környezetveszélyeztetés, míg a második mentesülési esetkör a kötelezést tartalmazó, véglegessé vált hatósági vagy jogerős bírósági határozat végrehajtásának közvetlen következményeként történt környezetkárosodásra vagy környezetveszélyeztetésre vonatkozik. ${ }^{41}$

Látható a magyar, illetve az uniós szint kapcsán, hogy a környezetvédelmi jogi szabályozás törekszik olyan helyzetet teremteni, amely esetében nem kerülhető meg, hogy a környezetkárosítás kapcsán érintett valamely személy az in integrum restitutio általános elvárását és az ennek megvalósítására hivatott helyreállítási kötelezettséget teljesítse. Ez egyes esetekben odáig is elvezet, hogy a közigazgatási jogi felelősséget és az ehhez kapcsolódó közigazgatási jogi kötelezettségeket rendkívül tágan értelmezzék a jogalkalmazók, hiszen a környezet állapotának helyreállítását mindenképpen biztosítani kell, s ez primátust élvez a felelősség egyértelmü és kétséget kizáró bizonyítása fölött.

\section{Az ügy első közigazgatási hatósági, majd bírósági szakasza}

Elöljáróban érdemes azt megjegyezni, hogy a Kúria az általam ismertetni kívánt, elvi tartalmat hordozó ítéletét egy felülvizsgálati eljárás keretében hozta. A felperes a Debreceni Munkaügyi és Közigazgatási Bíróság (a továbbiakban: elsőfokú bíróság) elsőfokú ítéletét támadta meg a Kúria előtt, amely ügy azért került előbbi elé, mert a felperes sérelmezte az Országos Környezetvédelmi és Természetvédelmi Főfelügyelőség (mint másodfokon eljáró közigazgatási hatóság) környezetvédelmi ügyben hozott közigazgatási határozatát. Az elsőfokon eljáró környezetvédelmi hatóság jelen ügyben a Hajdú-Bihar Megyei Kormányhivatal volt. Az ügy középpontjában a korábbiakban már említett kármentesítés egyik részmozzanatát képező tényfeltárásra kötelezés állt, amelyet a felperes álláspontja szerint nem jogszerüen írtak elő. Érdemes még azt is megjegyezni, hogy jelen ügyben a tényállás egészen a 2000-es évek elejéig, sőt egyes vonatkozásaiban még korábbra nyúlik vissza, azonban csak a 2010-es évek végén került az ügy a Kúria elé, amely az ítéletét végül 2019-ben hozta meg. Ezzel arra kívánok rávilágítani, hogy a környezetvédelmi ügyek az idő múlásával nemhogy veszítenének jelentőségükből abban a tekintetben, hogy a jogi kérdés már nem áll fenn, hanem éppen ellenkezőleg: két évtized elmúltával egyegy ügyben a környezeti állapot jogi eszközökkel történő helyreállítása ugyanúgy releváns marad, s az ügy környezetvédelmi szempontból egyáltalán „nem évül el”.

Jelen esetben „a felperes túzihorganyzó üzemével kapcsolatos panaszkivizsgálás során 2001. január 18-án talajminta-vételezést tartottak. A talajminták vétele az üzem kerítésén kívül, de közvetlenül a mellette futó árok talajából történtek, amely árok a szomszédos szántóföldhöz tartozik és egy magánszemély tulajdonában áll." Az eredmények kimutatták a fémszennyezés tényét, ezen belül is a cinkszennyezés volt a számottevő. A tűzihorganyzás során jelentős mennyiségü, folyékony cink

${ }^{41}$ Kvt. 102/A. § (1). 
tartalmú veszélyes hulladék keletkezik, amelynek elhelyezése a telephely kerítése melletti betonmedencékben történik.

A felperes nyilatkozata szerint a telephely korábban más tulajdonában állt, akinek a galvanizálási tevékenysége okozhatott környezetszennyezést, ugyanakkor a felperes által 1995-ben megvásárolt telephelyről készített környezeti állapotfelmérés nem tárt fel jelentős környezetszennyezést.

A betonmedencéktöl 2-3 méterre található mintavételi árokba a telephely létesítésétől kezdve folyamatos csapadékvíz-kivezetés történt, amely lehetővé tette a csapadékvízbe esetlegesen bemosódó szennyezés közvetlen kijutását. Mindezek okán a felperest kötelezték a talaj- és talajvízszennyezés tényfeltárására.

A felperes fellebbezéssel élt a határozat ellen, amelyet a föfelügyelőség helyben hagyott. A másodfokú hatóság helybenhagyó határozatával szemben a felperes bírósághoz fordult, ${ }^{42}$ de mind az elsőfokú, mind a másodfokú bíróság hatályában fenntartotta az elsőfokú közigazgatási hatóság tényfeltárásra kötelező határozatát.

Miután valamennyi jogorvoslati lehetőségét kimerítette a felperes, részletes környezeti tényfeltárási tervet készíttetett, amelyet elfogadott a felügyelőség. A később benyújtott tényfeltárási záródokumentációt szintén elfogadták, azzal, hogy a felperes nyújtson be müszaki beavatkozási tervet. A müszaki beavatkozási terv benyújtására kötelező határozat ellen a felperes szintén fellebbezett, de arra további két alkalommal újra kötelezték.

Ezt követően, immáron 2007. október 30-án egyeztető tárgyalás zajlott le a felügyelőség és a felperes képviselöi között, mely tárgyaláson elhangzottakról a felek jegyzőkönyvet készítettek. A jegyzőkönyvben rögzítésre került, hogy a felperes vállalja a kimutatott és lehatárolt szennyeződés komplex értékelésének keretében az emberi egészségre és az ökoszisztémára, illetve a környezeti elemekre vonatkozó helyspecifikus mennyiségi kockázatfelmérés, valamint a szennyező anyagok viselkedésének, terjedésének térbeli és időbeli előrejelzésére vonatkozó értékeléséről dokumentáció elkészíttetését. Rögzítésre került továbbá a jegyzőkönyvben, hogy a felperes a dokumentáció elkészítésével nem ismeri el a környezetszennyezés okozói felelősségét, és a kármentesítés végzésének kötelezettségét nem vállalja, valamint, hogy a felügyelőség a tényfeltárás elfogadása, valamint a műszaki beavatkozási terv készítésének elrendelése tárgyában hozott határozatát 8 napon belül visszavonja, és a kármentesítési eljárást folytatja.

2008. július 14-én benyújtották a mintavételi zárójelentést és a humán-egészségügyi kockázatbecslést, amely utóbbi a talajszennyezettséget vizsgálva megállapította, hogy a szennyezett termöföldön termesztett növények elfogyasztása kockázattal jár, míg a talajvíz esetében a legnagyobb mért szennyezőanyag-koncentrációk még talajvízhasználat esetén sem járnak a megengedhetőnél nagyobb kockázattal. A kockázatbecslést az egyik korábbi telephely-tulajdonos nyújtotta be. A mintavételi zárójelentés kapcsán hiánypótlást adtak ki, amelyben kérték a zárójelentést benyújtó gazdasági társaságot, hogy a szomszédos szántóföld területén történt talajszennyezés térbeli (horizontális, vertikális) lehatárolását végezze el, valamint a talajszennyezö-

${ }^{42}$ Később lesz utalás a Hajdú-Bihar Megyei Bíróság 6.K.30.383/2001/5. számú és 2002. március 5. napján kelt ítéletére mint ítélt dologra. 
dés megszüntetésére további, a termőföld védelmére irányuló javaslatokat dolgozzon ki. A gazdasági társaság azonban erre akként reagált, hogy ezek elkészítésére a korábbi telephely-tulajdonostól nem kapott megbízást. A korábbi telephely-tulajdonos válaszolt a hiánypótlási felhívásra, mely szerint a talajszennyezés lehatárolása a tényfeltárási záródokumentációban és kiegészítéseiben már megtörtént, melyet a felügyelőség elfogadott, a talajszennyezés megszüntetésére pedig mind a tényfeltárási záródokumentáció, mind a kockázatbecslés tartalmaz javaslatokat. Mindezek miatt kérték, hogy a felügyelöség az elöírt feladatok teljesítésétől tekintsen el.

Ezt követően egy újabb egyeztetés történt a felügyelőségen, amelyről készült emlékeztetőben rögzítésre került, hogy a felperes a talajszennyeződés lehatárolását bemutató dokumentációt hiánypótlásként benyúitja, és a szomszédos szántó művelési ágú területen található árok tulajdonjogának tisztázása, illetve a területen lévő árok kivett területté nyilvánítása ügyében 8 napon belül nyilatkozni fog. 2009. március 24. napján érkezett a felperes nyilatkozata, melyben jelezte, hogy az árok nem az ő tulajdona, így a müvelési ágból való kivonás ügyében nem tud eljárni.

Erre reagálva egy újabb hiánypótlási felhívás került kiadásra, amely alapján a korábbi telephely-tulajdonosnak ki kell dolgoznia olyan megvalósítható javaslatot a talajszennyeződés megszüntetése érdekében, amely mind talajvédelmi, mind környezetvédelmi szempontból elfogadható. Ezen hiánypótlás nem került benyújtásra, s így nem került kidolgozásra a talajszennyeződés megszüntetése érdekében megteendő intézkedés.

\section{Az ügy megismételt közigazgatási hatósági eljárási szakasza}

Innentöl datálható az ügy új szakaszba érkezése. A Hajdú-Bihar Megyei Kormányhivatal (a továbbiakban: elsőfokú hatóság) megismételt tényfeltárásra kötelezte a felperest 2015. július 23. napján kelt határozatával, mégpedig a korábban benyújtott tényfeltárási záródokumentációban és a kiegészítéseiben bemutatott szennyezettség vonatkozásában. Ennek szükségességét az indokolta, hogy az előző tényfeltárás óta annyi idő telt el, hogy változás következhetett be a szennyezettség koncentrációja és kiterjedése, továbbá ezek környezeti és humán-egészségügyi kockázata tekintetében. E kötelező határozat ellen nyújtott be a felperes fellebbezést, amelyben egyrészt a határozat megsemmisítését, másrészt új eljárásra utasítást kért, továbbá másodlagosan azt kérte, hogy az elsőfokú határozat megváltoztatására úgy kerüljön sor, hogy abban megállapítsák, hogy a felelősség nem őt terheli a környezet tekintetében.

A Nemzeti Élelmiszerlánc-Biztonsági Hivatal 2015. október 14. napján azt a szakértői véleményt adta, hogy talajvédelmi szempontból a mezőgazdasági múvelési ágú területen a talajszennyezés (horizontális, vertikális) lehatárolását el kell végezni, továbbá a talajszennyeződés megszüntetésére és a termőföld minőségének védelmére javaslatot kell kidolgozni. A szakhatóság a rendelkezésre álló iratok alapján megállapította, hogy a megismételt eljárás, részletes tényfeltárás talajvédelmi szempontból indokolt. 
A fellebbezés folytán eljáró Országos Környezetvédelmi és Természetvédelmi Föfelügyelőség (a továbbiakban: másodfokú hatóság) 2016. január 13. napján kelt határozatával az elsőfokú határozatot csupán „annyiban változtatta meg, hogy a tényfeltárási záródokumentáció benyújtási határidejét a másodfokú határozat jogeröre emelkedését követő 10 hónapban határozta meg, egyebekben az elsőfokú határozatot helybenhagyta".

A másodfokú hatóság álláspontja szerint a fellebbezésben foglaltakkal ellentétben az elsőfokú hatóság tisztázta azt a jogilag releváns körülményt, miszerint a felperes telephelyén folytatott tevékenységére vezethető vissza a telephelyen és annak környékén észlelt szennyezettség, így felelősségét nem mentette ki. Ezt a szakhatósági állásfoglalással is megindokolta, amely kimondta, hogy a felperes tűzihorganyzási tevékenysége során nagy mennyiségü, folyékony cink tartalmú, veszélyes hulladék keletkezik, melynek elhelyezése a tárgyi ingatlan kerítése melletti betonmedencékben történik. A szakhatóság a záródokumentáció és annak kiegészítése alapján megállapította, hogy a tényfeltárás öt ütemben zajlott. A vizsgálati eredmények a talaj esetén az arzén, kadmium, króm, réz, molibdén, ólom, cink, valamint bizonyos területeken szénhidrogén, a talajvíz esetén az arzén, nikkel, szelén és cink vonatkozásában a $B$ szennyezettségi határértéket meghaladó szennyezést mutattak. A szakhatóság megállapította továbbá, hogy a szennyezéssel érintett területeken a kockázatbecslés benyújtása, azaz 2008 óta további vizsgálatok nem történtek, a müszaki beavatkozás nem történt meg. A szennyezés terjedése és jelenlegi kiterjedése a felszín alatti víz tekintetében nem tisztázott. Mindezek alapján állapította meg a másodfokú hatóság, hogy az elsőfokú hatóság eljárása anyagi és eljárásjogi szempontból is megfelelt a jogszabályi rendelkezéseknek. ${ }^{43}$

\section{Az ügy elsőfokú bírósági szakasza ${ }^{44}$}

Az Országos Környezetvédelmi és Természetvédelmi Főfelügyelöség határozatát a felperes megtámadta, ennek következtében pedig a Föfelügyelőség alperesi pozícióba került az elsőfokú bíróság előtti eljárásban. A felperes érveit a következőkben lehet megragadni:

- A Kvt. 102. §-át, valamint a kormányrendelet 21. § (2) bekezdését az alperesi hatóság megsértette.

- A felperes leszögezte, hogy a tevékenységével összefüggésbe hoztak olyan szennyező anyagokat is, például az arzént, a nikkelt, a szelént, az ólmot és az alifás szénhidrogéneket, amelyek abból nem származhattak, viszont a telephely korábbi tulajdonosának tevékenységéből igen. Csupán feltételezés az alperesi hatóság azon álláspontja, hogy e szennyező anyagok a felperes tevékenysége okán kerültek a talajba, valamint a felszín alatti vízbe.

43 „Az ügy első közigazgatási hatósági, majd bírósági szakasza”, valamint „Az ügy megismételt közigazgatási hatósági szakasza" című fejezet kivonat a Debreceni Közigazgatási és Munkaügyi Bíróság 11.K.27.275/2016/32. sz. ítéletéből.

${ }^{44}$ E fejezetben az ítélet [4], [5], [6] és [8] pontja került hivatkozásra, néhány esetben stilisztikai változtatásokkal. 
- A felperes sérelmezte azt is, hogy majdhogynem hét évig, 2008 közepétöl 2015. február 2. napjáig az alperes nem lépett elöre az ügyben, amelyböl az következett, hogy nem tudta elbírálni a korábbiakban benyújtott részletes tényfeltárási záródokumentációt.

Ezzel szemben, az alperesi hatóság ellenkérelmében a következőket fejtette ki:

- A felperes tényállítása megalapozatlan és megkérdőjelezhető, mivel 1996-ban, annak érdekében, hogy a felperes környezetvédelmi engedélyt szerezzen tüzihorganyzási tevékenységre, vizsgálatok lefolytatására került sor, s ennek a dokumentációját a megfelelő vizsgálati eredményekre tekintettel a környezetvédelmi hatóság elfogadta.

- Ezzel ellentétesen 5 évvel később, mégpedig 2001-ben, amikor a hatósági mintavételi eredmények már kimutatták a szennyezést, a felperes úgy nyilatkozott, hogy a terület szennyezettsége a korábbi tulajdonos tevékenységére vezethető vissza.

- Az iratok 1996 óta állnak rendelkezésre, ugyanakkor a felperes az elmúlt 15-20 év alatt nem szolgáltatott egyetlen olyan új és hiteles bizonyítékot az eljáró környezetvédelmi hatóság elé, amellyel cáfolni tudta volna az alperesi ténymegállapítással ellentétben azt, hogy a Kvt. 102. §-ában foglaltak szerint kétséget kizáróan nem őt terheli a felelősség.

Az elsőfokon eljáró bíróság szerint a felperes keresete nem volt megalapozott, amit azzal támasztott alá, hogy az 1996. évi vizsgálati eredmények - szemben a 2001. évi eredményekkel - még nem mutattak ki szennyezést. Bizonyított tehát az, hogy a szennyezés okozója csak a felperes lehet. A korábbiakban, a Hajdú-Bihar Megyei Bíróság 6.K.30.383/2001/5. számú és 2002. március 5. napján kelt ítéletével a felperesnek a tárgyban benyújtott keresetét már elutasította, s e szerint a felperes sem vitatta azt, hogy a környezetszennyezés már megtörtént.

A környezetszennyező anyagok között a felperes tủzihorganyzó tevékenységéhez kapcsolható cinkszennyezés mutatható ki a talajban és a talajvízben egyaránt. Az ítéletben rögzítésre került, hogy a cinkszennyezés kétségtelenül a felperes tevékenységével hozható összefüggésbe.

A szennyezettséggel érintett és feltárandó terület kiterjesztése - a 2001. évi kötelezéshez képest - azzal indokolható, hogy a cinkszennyezéssel érintett ingatlant 1998 óta a felperes használja, s ez az ingatlan azon ingatlanok gyürüjében helyezkedik el, amelyek vonatkozásában a felperes korábban úgy nyilatkozott, hogy azok mentesek a szennyezéstöl. A bíróság akként vélekedett, hogy

az eljáró hatóság a kármentesítés részletes tényfeltárási szakaszának megismétléséröl a jogszabályoknak megfelelően döntött, és kötelezte a felperest annak elvégzésére, tekintettel arra, hogy a Kvt. 102. §-ában foglaltak szerint a felperes egyelöre kétséget kizáróan nem bizonyította felelősségének hiányát - hatóság által elfogadott tényfeltárási záródokumentáció hiányában - a tüzihorganyzó területén fellelhető szennyezés tekintetében. 


\section{Az ügy Kúria elötti szakasza ${ }^{45}$}

Az ügyben a felperes felülvizsgálati kérelmet nyújtott be, amelyben azt kérte, hogy az elsőfokú bíróság ítéletét és az alperes határozatát helyezzék hatályon kívül. A Kúria elé került jogkérdés a megismételt részletes kármentesítési tényfeltárás jogszerüségére vonatkozott. E kérdésben a felperes érvei a következők voltak:

- Nem igazolt, hogy valamennyi szennyezés az ő tevékenységével lenne összefüggésbe hozható. A Hajdú-Bihar Megyei Bíróság ítélete kizárólag a cinkszenynyezés vonatkozásában mondta ki annak a felperesi tevékenységgel való összefüggését. Ugyanakkor a cinkkomponensen kívül a kadmium-, króm-, réz-, nikkel-, ólomkomponensekre is elrendelte az alperes a szennyezés lehatárolását, amelyeket azonban a felperes által benyújtott tényfeltárási záródokumentáció tartalmaz.

- A felperes telephelyén az ott felhasznált technológia olyan jellegü, amelyböl nem származhatnak a kadmium, króm, réz, nikkel, ólom szennyező anyagok, ezért azok vizsgálatára nem kötelezhető jogalap hiányában.

A Kúria ítélete szerint a felperes felülvizsgálati kérelme nem megalapozott. Ennek megalapozása során a Kúria utalt a környezetvédelmi törvény 101. § (1) bekezdésére és (2) bekezdésének $c$, pontjára mint a jogi felelősség általános alapjára és a környezethasználót terhelö kötelezettségekre, illetve a 102. § (1) bekezdésére mint a környezetkárosodásért való felelősségre vonatkozó vélelemre. Utalt továbbá arra is, hogy kármentesítésre kötelezett az, aki a Kvt. 101-102/A. §-ában meghatározottak szerint felelősséggel tartozik, továbbá a kormányrendelet azon rendelkezésére, amely kimondja, hogy a környezetvédelmi hatóság a tényfeltárási záródokumentáció figyelembevételével dönt a záródokumentáció elbírálásáról, valamint a szennyezettséggel, károsodással kapcsolatos további feladatokról. Ez utóbbi magában foglalhatja azt is, hogy a tényfeltárás folytatását rendeli el, vagy éppen a beavatkozás szükségességét állapítja meg.

Az eljárás során bebizonyosodott, hogy a felperes környezethasználónak tekinthetö, valamint az is, hogy egyértelmü kimentésröl nem beszélhetünk, s más személy felelőssége sem állapítható meg. Egy res iudicata-val állunk szemben a Hajdú-Bihar Megyei Bíróság ítéletében annak tekintetében, hogy a cinkszennyezés összefüggésbe hozható a felperes tevékenységével, illetve a korábbi telephely-tulajdonos felelőssége nemcsak kétséget kizáróan nem bizonyított, hanem egy 1996. évi vizsgálat alapján az egyáltalán nem mutatható ki, azonban öt évvel később, 2001-ben, amikor már a felperes volt a telephely tulajdonosa, a szennyezés már kimutathatóvá vált.

A szennyezés és a folytatott tevékenység közötti kapcsolat, teljes érvényű kimentés hiányában, nem zárható ki. A jogszabályi rendelkezés e megalapozott feltételezést a tényfeltárás kötelezettségének alapjaként szabályozza. Ezért a kötelezés nem tekinthető jogellenesnek.

${ }^{45}$ E fejezetben az ítélet [9], [10], [13]-[17], [22] és [24] pontja került felhasználásra. 
A Kúria szerint a felperes jogszerüen kötelezhető a tényfeltárásra a cinkszenynyezés tekintetében az ítélt dolog miatt (utalva itt a Hajdú-Bihar Megyei Bíróság 2002. évi ítéletére), a többi szennyezőanyag tekintetében pedig a Kvt. vélelme és a kimentés hiánya miatt.

A Kúria döntésének elvi tartalma pedig a következő:

Ha a felelősség nem állapítható meg egyértelműen a környezetveszélyeztetésért, akkor elsődlegesen a környezethasználó kötelezettségei kerülnek megállapításra a jogi szabályozás okán. E környezethasználó tevékenységéről - kimentés hiányában vélelmezi a jogszabály, hogy az esetlegesen károsító hatású lehet. A tényfeltárás egyebek között azt a célt is szolgálja, hogy ebben a tekintetben tisztázni lehessen egyértelműen a károsító hatás eredetét (okát vagy okozóját).

\section{Konklúzió}

A következtetések levonásakor érdemes megkülönböztetést tenni a szennyezőanyagok között. Ahogy a tényállásból látható, a felperes cinkszennyezése megállapítható (bizonyított) volt, így annak kapcsán kérdés nem merül fel. A többi szennyezőanyag (kadmium, króm, réz, nikkel, ólom) vonatkozásában azonban szükség volt a vélelem alkalmazására, amely jelen esetben lehetővé tette, hogy a felperes a kötelezettségek, valamint a felelősség alól ne mentesülhessen ezen szennyezőanyagok tekintetében sem.

Bár a kormányrendelet kimondja, hogy kármentesítésre kötelezett az, aki a Kvt. 101-102/A. §-a szerint felelősséggel tartozik, a Kvt. e rendelkezéseit a Kúria ítéletével egybevetve az rajzolódik ki, hogy a felperes azért volt kötelezhető kármentesítésre, ezen belül pedig tényfeltárásra, mert a felperes tevékenysége miatt történt nemcsak a cinkkel okozott környezetkárosodás, hanem vélelmezetten a többi szenynyezőanyaggal okozott környezetkárosodás is. Az ugyan bebizonyosodott, hogy a felperes ingatlanán a talajba és talajvízbe cinket juttató környezetkárosító tevékenység történik, azonban az nem, hogy a többi szennyezőanyag is onnan származik. A vélelem alkalmazásával a környezetvédelmi hatóság helyzete jelentősen egyszerübbé vált, amihez a konkrét esetben hozzájárult a felperes korábbi, az érintett ingatlan szennyezettségének hiányára vonatkozó nyilatkozata. E perdöntő állítását a későbbiekben a felperes nem tudta megmásítani, s a vélelem folytán reá háruló bizonyítási teher következtében nem tudta bizonyítani azt, hogy a többi szennyezőanyag vonatkozásában a felelősség nem őt terheli.

Fontos leszögezni, hogy a környezetvédelem terén egyes esetekben indokolt a kötelezettségek és a felelősség ily módon történő tág értelmezése, s erre a vélelem jogtechnikai eszköze kiváló lehetőséget teremt, hiszen a jogalkalmazó keze meg van kötve bizonyos ok-okozati, s ezáltal a felelösséget megalapozó összefüggések bizonyításában. Véleményem szerint a Kúria elvi tartalmat hordozó ítélete rendkívül előremutató abban a tekintetben, hogy a jogalkalmazás hogyan szolgálhatja a környezetvédelem érdekeit hatékonyabban. 